\title{
Eosinophilic granuloma of skull in a 7 year child: Diagnosed on fine needle aspiration cytology
}

\section{Ince iğne aspirasyon biyopsisi ile kafatasında eozinofilik granülom tanısı alan 7 yaşında çocuk olgu}

\author{
Ruchi Agarwal*, Parveen Rana, Amrita Duhan, Sanjay Verma, Rajnish Kalra
}

Department of Pathology (Assist. Prof. R. Agarwal, MD., Assist. Prof. P. Rana MD., Assist. Prof. A. Duhan, MD., S. Verma, MD.), Pt. B.D Sharma Post Graduate University of Medical Sciences, Rohtak (Haryana) IN-124 001 India. Department of Pathology (Prof. K. Rajnish, MD.), Bhagat PhoolSingh, Government medical college for women, Khanpur Kalan, Sonepat IN- 124305 India

\begin{abstract}
Eosinophilic granuloma is a rare bone tumor, representing less than $1 \%$ of all bone tumors. Eosinophilic granuloma is the benign form of three clinical variants of Langerhans cell histiocytosis (LCH). It commonly affects children and young adults, particularly males. The characteristic cytologic features of eosinophilic granuloma include langerhans cells in a characteristic milieu which includes histiocytes, eosinophils, neutrophils and lymphocytes. We are reporting a case of eosinophilic granuloma of skull in a 7 years child diagnosed on fine needle aspiration cytology (FNAC). We here by emphasize the importance of rapid and reliable diagnosis of LCH by FNAC and the need to consider the possibility of LCH in the differential diagnosis of a slide showing a large number of histiocytes and eosinophils.
\end{abstract}

Keywords: Cytology, eosinophilic granuloma, langerhans cell, skull

\section{Özet}

Eozinofilik granülom nadir bir kemik tümörü olup, tüm kemik tümörlerinin \%1'inden azını oluşturmaktadır. Eozinofilik granülom, üç klinik varyantı olan Langerhans hücreli histiositozisin (LHH) benign formudur. Çoğunlukla çocukları ve genç erişkinleri özellikle de erkekleri etkiler. Eozinofilik granülomun karakteristik sitolojik yapısı histiyositler, eozinofiller, nötrofiller ve lenfositleri içeren tipik bir ortamda langerhans hücrelerinin bulunmasıdır. Bu makalede ince iğne aspirasyon biyopsisi (İAB) ile tanı alan yedi yaşında bir eozinofilik granülom olgusu sunulmaktadır. Burada özellikle İİAB ile LHH'e hızlı ve güvenilir bir şekilde tanı koyulabileceğini ve üzerinde çok sayıda histiyosit ve eozinofil bulunan bir ince iğne aspirasyon yaymasında ayırıcı tanıda LHH olasılığının bulunması gerektiğini vurgulamak istiyoruz.

Anahtar sözcükler: Sitoloji, eozinofilik granülom, langerhans hücresi, kafatas1

Geliş tarihi/Received: May 05, 2013; Kabul tarihi/Accepted: July 10, 2013

*Corresponding author:

Dr. Ruchi Agarwal, Department of Pathology, 673/35, Janta Colony, Rohtak-124001, Haryana, India. E-mail: pg.ruchi@gmail.com

\section{Introduction}

Eosinophilic granuloma is one of the rarest bone tumors representing less than $1 \%$ of them. In $90 \%$ of cases, it afflicts children under the age of 10. There is predilection for males (2:1) [1] Solitary Eosinophilic Granuloma (EG) accounts for the majority of the LCH cases, usually involving bone and less commonly the lymph nodes, skin and lung [2]. Langerhans cell histiocytosis (LCH) is characterized by clonal proliferation of a special kind of histiocytic antigen presenting dendritic type of cell named as Langerhans cell (LCs) [3]. Eosinophilic granuloma has got a good prognosis; it may regress spontaneously and is extremely radiosensitive [4]. 


\section{Case report}

A seven-year-old boy presented to surgery out-patient department with a painless swelling over right side of forehead for 15 days. There was no history of trauma, headache or vomiting. Systemic examination was unremarkable. Local examination revealed a swelling $1.5 \mathrm{~cm}$ in diameter in right frontal region which was firm, slightly mobile and non-tender. The overlying skin appeared normal.

Routine hematological and biochemical investigations were within normal limits. X-ray skull showed a well demarcated $2 \mathrm{~cm}$ diameter oval osteolytic lesion in the right frontal bone. CT scan revealed an osteolytic lesion in the right frontal bone with erosion of the outer table along with adjacent soft tissue involvement.

FNAC of the swelling was performed. Smears stained with Romanoswky stain revealed sheets and singly scattered histiocytes and eosinophils. They were accompanied by polymorphic population of cells including neutrophils, lymphocytes, foamy histiocytes and multinucleate giant cells. The histiocytes were large cells with oval to reniform shape nuclei with nuclear grooving and abundant pale blue cytoplasm. The cytologic findings were suggestive of LCH (Figure 1). Histopathological examination was performed following surgical excision of the swelling which was consistent with findings of eosinophlic granuloma (Figure 2).

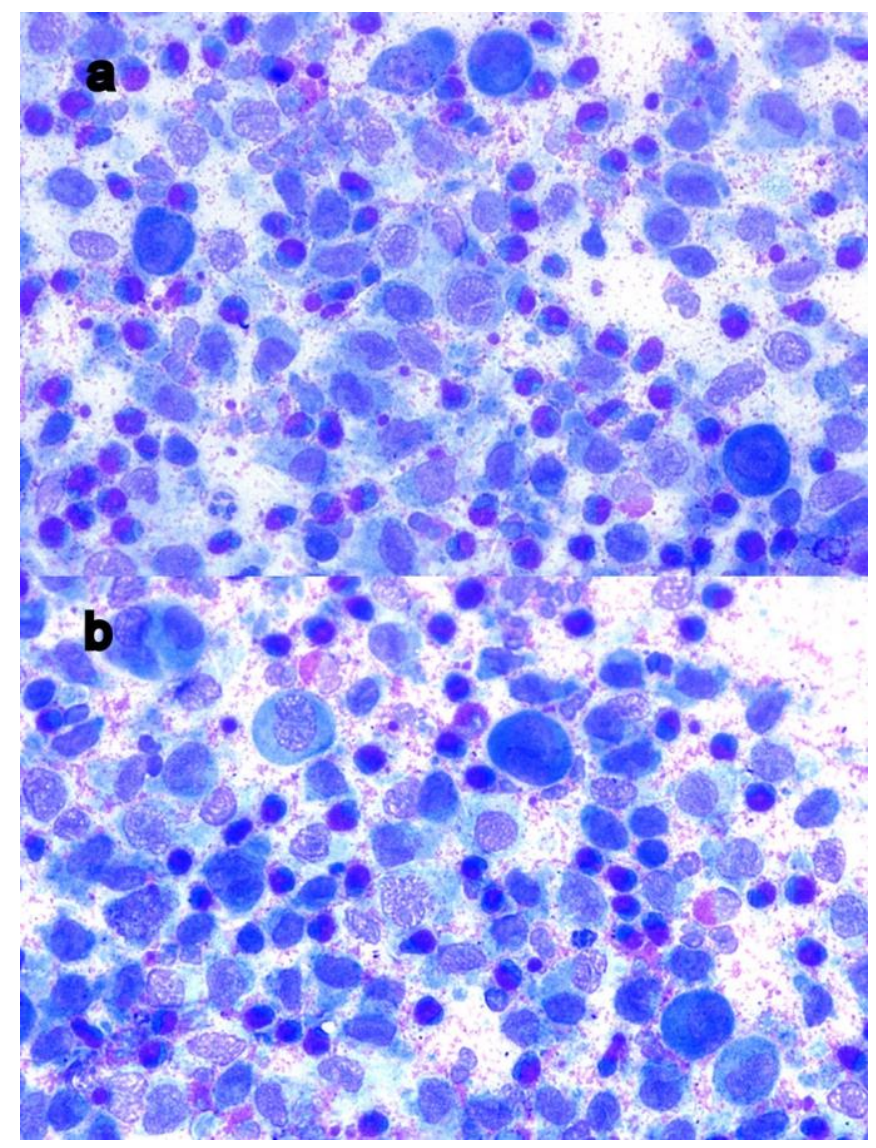

Figure 1a and b. Photomicrograph of FNA from swelling forehead revealing scattered Langerhans cells with prominent nuclear grooves accompanied by many eosinophils (Romanowsky stain X400 and x400). 


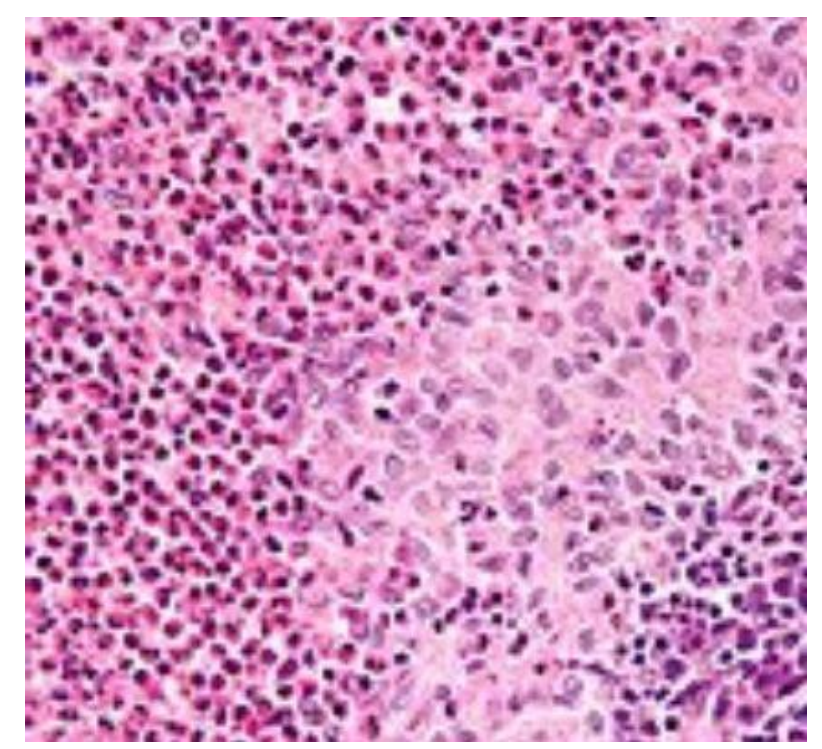

Figure 2. Histopathology of forehead swelling revealing features of Eosinophilic granuloma (H\&E X 200).

Patient was further investigated and no other systemic involvement was found. He was well and asymptomatic during one year follow up without any further treatment.

\section{Discussion}

Eosinophilic granuloma (EG) is a rare bone tumor, representing less than $1 \%$ of all bone tumors [1]. The term "eosinophilc granuloma" was first introduced by Lichtenstein and Jaffe in 1940. Eosinophilic granuloma is the benign form of three clinical variants of LCH; the other two variants are Letterer-Siwe disease and Hand-Schuller-Christian disease [4]. The etiology of LCH is unknown and there is continuing debate whether this condition is neoplastic or non-neoplastic [2]. Inflammation, autoimmunity and loss of controlled proliferation of Langerhans cells are assumed etiologies [5].

EG is the mildest and commonest form of Histiocytosis-X malady [6]. It commonly affects children and young adults, particularly males. Any bone can be involved; the more common sites include the skull, mandible, spine, ribs and the long bones [4]. EG can be asymptomatic or can present as localized pain, tender swelling and fever. Rarely does it present with epidural hematomas, suppression of bone marrow and pathological fracture. Headache, neurological symptoms, chronic mastoiditis and exophthalmos may be seen in cases of skull lesions [6]. In our case, patient presented with a swelling in forehead only. Hematological examination shows leukocytosis and mild eosinophilia in $7 \%$ of patients. Erythrocyte sedimentation rate is over the normal levels [5].

The clinical course is related to the number of organs affected at the time of diagnosis, with an overall survival of $95 \%$ for patients with unifocal disease; $10 \%$ of the patients with unifocal disease eventually progress to multisystem disease [6]. It has a highly variable course with partial or complete healing of the lesion, recurrence after treatment, progression or spontaneous remission without treatment [7].

The radiological depiction of eosinophilic granuloma is necessary as to determine the activity and nature of the tumor. Plain X-ray depicts the size and borders of the lesion. CT and MRI demonstrate the exact size and borders of the tumor as well as the situation of the surrounding tissues and a probable hematoma. Ultrasound is only used for guided biopsies. The clinical and the radiologic findings are often not specific enough to determine the diagnosis [5]. Cytology is very helpful in arriving the diagnosis of EG of bone [2]. Diagnosis is set by histological examination.

The classic cytologic features of eosinophilic granuloma include high cellularity composed of sheets and scattered langerhans cells admixed with polymorphous 
population of numerous eosinophils, neutrophils, lymphocytes, plasma cells, multinucleated giant cells and macrophages [2, 8]. Charcot-Leyden crystals may also be observed in the background [9]. The key to diagnosis is to identify langerhans cells through its characteristics features of nuclear grooves and nuclear pseudoinclusions. Degree of eosinophil infiltration varies and thus their number varies from scant to abundant in cytology smears [2]. Their presence can attract attention to the diagnosis. In the present case, the aspirate was highly cellular, with predominance population of Langerhans cells and giant cells along with significant numbers of accompanying inflammatory cells especially eosinophils. There were no Charcot Leyden crystals. The lesion resembled a chronic granulomatous inflammation but based on the cytologic characteristics of histiocytes, diagnosis of eosinophilic granuloma was suggested. Osteomyelitis and Ewing's sarcoma in children, metastatic carcinoma and other benign and malignant primary tumors of bone in adults constitute the differential diagnosis of EG [10]

Histopathologically, EG is characterized by presence of langerhans cells with grooved, folded and indented nuclei in the appropriate milieu that includes variable numbers of eosinophils, lymphocytes, neutrophils, foam cells and multinucleate giant cells similar to osteoclast or touton type. An ultrastructural hallmark of LCs is the characteristic tennis racket shaped Birbeck granules in the cytoplasm [2, 6].

EG can heal without treatment while passing from childhood to adulthood. If not, the suggested treatment is the surgical curettage of the tumor or local infusion of cortisone. Chemotherapy, radiotherapy and systemic use of cortisone are effective for multiple bone lesions [11]. A recurrence rate of less than $20 \%$ has been reported in the literature with any form of treatment [12]. Surgical curettage was done in present case and patient was well and asymptomatic during one year follow up without any further treatment.

In summary, when accompanied by classical clinical and radiological features, LCH can be diagnosed by fine needle aspiration cytology because of the presence of characteristic langerhans cells and eosinophils.

\section{References}

1. Ando A, Hatori M, Hosaka M, Hagiwara Y, Kita A, Itoi E. Eosinophilic granuloma arising from the pelvis in children: A report of three cases. Upsala $\mathbf{J}$ Med Sci 2008: 113: 209-16.

2. Jain A, Alam K, Maheshwari V, Jain V, Khan R. Solitary eosinophilic granuloma of the ulna: Diagnosis on fine needle aspiration cytology. Journal of Cytol 2008; 25: $153-6$.

3. Jon A, Vinay K. White cells, lymph nodes, spleen and thymus. In Ramzi Sc, Vinay K, Tucker C, eds. Robbins pathologic Basis of Disease. 6th ed. W.B. Saunders Co. 1999:685.

4. Kaul R, Gupta N, Gupta S, Gupta M. Eosinophilic granuloma of skull bone. J Cytol 2009; 26: 156-7.

5. Kitsoulis PV, Paraskevas G, Vrettakos A, Marini A. A case of eosinophilic granuloma of the skull in an adult man: a case report. Cases Journal 2009; 2: 9144.

6. Weiss LM, Grogan TM, Muller-hermelink, Stein H, Dura T, Favara B, Paulli M, Feller AC. Langerhans cell histiocytosis. In: Jaffe ES, Harris NL, Stein H, Vardiman JW, editors. Pathology and genetics of tumors of haematopoietic and lymphoid tissue. Lyon: IARC Press; 2001; p: 280-2.

7. Chacha PB, Khong BT. Eosinophilic granuloma of bone. A diagnostic problem. Clin Orthop 1971; 80: 79-88.

8. Mukhopadhyay S, Mitra PK, Ghosh S. Touton like giant cell in lymph node in a case of langerhans cell histiocytosis. Journal of Cytol 2007; 24: 191-2. 
9. Kumar PV, Mousavi A, Karimi M, Bedayat GR. Fine needle aspiration of Langerhans cell histiocytosis of the lymph nodes. A report of six cases. Acta Cytol 2002; 46: 753-6.

10. Shetty S, Kumar A, Irshenavar SS. Eosinophilic granuloma of ileum: a case report. J Orthopaedics 2007; 4: 25.

11. Rawlings CE 3rd, Wilkins RH. Solitary eosinophilic granuloma of the skull. Neurosurgery 1984; 15: 155-61.

12. Plasschaert F, Craig C, Bell R, Cole WG, Wunder JS, Alman BA. Eosinophilic granuloma. A different behaviour in children than in adults. J Bone Joint Surg Br 2002; 84: 870-2. 